Review

\title{
Buses Running on Gas
}

\author{
${ }^{1}$ Relly Victoria Virgil Petrescu, ${ }^{2}$ Raffaella Aversa, ${ }^{3}$ Bilal Akash, \\ ${ }^{4}$ Taher M. Abu-Lebdeh, ${ }^{2}$ Antonio Apicella and ${ }^{1}$ Florian Ion Tiberiu Petrescu \\ ${ }^{I}$ ARoTMM-IFToMM, Bucharest Polytechnic University, Bucharest, (CE), Romania \\ ${ }^{2}$ Advanced Material Lab, Department of Architecture and Industrial Design, \\ Second University of Naples, 81031 Aversa (CE), Italy \\ ${ }^{3}$ Dean of School of Graduate Studies and Research, American University of Ras Al Khaimah, UAE \\ ${ }^{4}$ North Carolina A and T State University, USA
}

Article history

Received: 26-01-2018

Revised: 29-01-2018

Accepted: 03-02-2018

Corresponding Author: Florian Ion Tiberiu Petrescu ARoTMM-IFToMM, Bucharest Polytechnic University, Bucharest, (CE), Romania Email: scipub02@gmail.com

\begin{abstract}
Today, the transport problem is not only very diverse and complex but also highly disputed in terms of the optimal way of achieving modern and ecological transports. The energy and social crisis that occurred in the 1970s and 1980s, which then haunted the planet repeatedly, becoming a major crisis, could be successfully avoided by postponing and reprogramming until mankind managed to manage nuclear fission energy and renewable and sustainable green, hydropower, solar and wind power. Part of the oil and gas burnt, which were increasingly limited as international reserves, were saved or stored due to the transition to nuclear power generation, which allowed general public transport to diversify and electrify as a percentage of $70 \%$ (electric trains, trams, subways, trolleybuses). Anyway, petroleum and carboniferous was an ecological disaster for the entire planet, not to mention the negative effect of the greenhouse, global warming, with all the repercussions already known. Today we have about $35-40 \%$ of the green, sustainable, otherwise than hydrocarbon-based energy. Of course, that is not enough, but we have managed to avoid collapsing and prolong the life of oil reserves. In addition, we have also discovered new oil and gas reserves that help us further. The total renunciation of hydrocarbon energy was not and is not yet possible, but we can rethink its optimal use. A major advantage was the obtaining of new resources, deposits of natural gas, shale extracted from very large depths (due to the use of modern technologies). The shale gas discovered in the last 10-15 years helped us enormously. The advantage of these hydrocarbons is that they burn completely, without residue and almost without pollution. Pollution due to gas burning is extremely small, even insignificant. The major negative effects that have plagued the blue planet since the 1950s were mainly due to atomic and nuclear experiences, as well as massive oil burning. Now that we have massive gas reserves, practically non-polluting, it would be a shame not to use them, but to do it rationally. Do not stop modern green energies, which must be permanently multiplied and not massively burning gases to obtain electric demand and heat. But neither use them (gas) for domestic consumption (in the household cookers), it is not efficient. Gases should be used to make food in our homes and to equip certain types of vehicles.
\end{abstract}

Keywords: Machines, Mechanisms, Industrial Robots, Automation, Transportation, Design, Ecosystems, Gas, Bus 


\section{Introduction}

Today, the transport problem is not only very diverse and complex but also highly disputed in terms of the optimal way of achieving modern and ecological transports. The energy and social crisis that occurred in the 1970s and 1980s, which then haunted the planet repeatedly, becoming a major crisis, could be successfully avoided by postponing and reprogramming until mankind managed to manage nuclear fission energy and renewable and sustainable green, hydropower, solar and wind power.

Part of the oil and gas burnt, which were increasingly limited as international reserves, were saved or stored due to the transition to nuclear power generation, which allowed general public transport to diversify and electrify as a percentage of $70 \%$ (electric trains, trams, subways, trolleybuses). If electricity were produced only by burning hydrocarbons, the electrification of public transport would have been neither possible nor sustainable.

Global energy yields would have been greatly lost and hydrocarbon-based resources would have been exhausted for long, leaving aside that they are also very polluting and have generated a multitude of negative aspects from the planet, starting with air pollution, water pollution, soil and subsoil and the destruction of the environment, human and animal disease, flora and fauna and ecosystems.

Anyway, petroleum and carboniferous was an ecological disaster for the entire planet, not to mention the negative effect of greenhouse, global warming, with all the repercussions already known.

Today we have about $35-40 \%$ of the green, sustainable, otherwise than hydrocarbon-based energy. Of course that is not enough, but we have managed to avoid collapsing and prolong the life of oil reserves. In addition, we have also discovered new oil and gas reserves that help us further. The total renunciation of hydrocarbon energy was not and is not yet possible, but we can rethink its optimal use.

A major advantage was the obtaining of new resources, deposits of natural gas, shale extracted from very large depths (due to the use of modern technologies). The shale gas discovered in the last 10-15 years helped us enormously.

The advantage of these hydrocarbons is that they burn completely, without residue and almost without pollution. Pollution due to gas burning is extremely small, even insignificant. The major negative effects that have plagued the blue planet since the 1950s were mainly due to atomic and nuclear experiences, as well as massive oil burning. Now that we have massive gas reserves, practically non-polluting, it would be a shame not to use them, but to do it rationally.

Do not stop modern green energies, which must be permanently multiplied and not massively burning gases to obtain electric demand and heat.
But neither use them (gas) for domestic consumption (in the household cookers), it is not efficient.

Gases should be used to make food in our homes and to equip certain types of vehicles.

The issue of introducing new types of vehicles that work differently than petrol, diesel or gasoline has not yet been resolved.

Electric cars are in full swing and expansion, but still have many technical difficulties that make them hard to reach the majority of the population. They are not yet sufficiently large, they are not reliable enough, they do not adapt to the extreme conditions, in the heavier winters when they do not start at excessive heat, at high humidity conditions, etc. I'm still hard to feed, to implement and even very expensive, being hard to buy by the vast majority of people.

On the other hand, electric buses declared to be successful in China cannot work in all Chinese regions and do not yet adapt to temperate conditions, cold winters, heavy wetlands, or excessive heat. Various private, stateowned, governmental or local governments have attempted to deploy electric buses, but unsuccessfully. For this reason, it has returned rapidly to the classic diesel, but due to the new environmental demands, the issue of giving up their services is seriously questioned.

Then we put it right now, right away. In the future, new engines, modern electric, new hybrids, extending the fuelcell hydrogen system, the emergence and implementation of water or air buses, but what do we do right now and in the next 30-50 years? (it is the real question that those who need to purchase new buses, implement and use for the people in their local communities).

The present paper attempts to present a viable, compromise solution, on a short and medium term, to this important issue, the answer we make to the previous question being a definite one, is the time to switch to gas buses for a period of about 30-50 years (Aversa et al., 2016a; 2016b; 2016c; 2016d; 2017a; 2017b; 2017c; 2017d; 2017e; Mirsayar et al., 2017; Cao et al., 2013; Dong et al., 2013; De Melo et al., 2012; Garcia et al., 2007; Garcia-Murillo et al., 2013; He et al., 2013; Lee, 2013; Lin et al., 2013; Liu et al., 2013; Padula and Perdereau, 2013; Perumaal and Jawahar, 2013; Petrescu and Petrescu, 1995a; 1995b; 1997a; 1997b; 1997c; 2000a; 2000b; 2002a; 2002b; 2003; 2005a; 2005b; 2005c; 2005d; 2005e, 2016a; 2016b; 2016c; 2016d; 2016e; 2013; 2012a; 2012b; 2011; Petrescu et al., 2009; 2016a; 2016b; 2016c; 2016d; 2016e; 2017a; $2017 \mathrm{~b} ; 2017 \mathrm{c} ; 2017 \mathrm{~d} ; 2017 \mathrm{e} ; 2017 \mathrm{f} ; 2017 \mathrm{~g} ; 2017 \mathrm{~h}$; $2017 \mathrm{i} ; 2017 \mathrm{j} ; 2017 \mathrm{k} ; 2017 \mathrm{l} ; 2017 \mathrm{~m} ; 2017 \mathrm{n} ; 2017 \mathrm{o}$; $2017 \mathrm{p} ; 2017 \mathrm{q} ; 2017 \mathrm{r} ; 2017 \mathrm{~s} ; 2017 \mathrm{t} ; 2017 \mathrm{u} ; 2017 \mathrm{v}$; 2017w; 2017x; 2017y; 2017z; 2017aa; 2017ab; 2017ac; 2017ad; 2017ae; Petrescu and Calautit, 2016a; 2016b; Reddy et al., 2012; Tabaković et al., 2013; Tang et al., 2013; Tong et al., 2013; Wang et al., 2013; Wen et al., 
2012; Antonescu, 2000; Antonescu and Petrescu, 1985; 1989; Antonescu et al., 1985a; 1985b; 1986; 1987; 1988; 1994; 1997; 2000a; 2000b; 2001).

\section{Materials and Methods}

Shale gas is an improper designation of a gas source by applying a mechanical release process to the host rock (the rock containing the gas). The improper name derives from the fact that in Romanian literature no equivalency (at the level of vocabulary) between the rocks resulting from the incremental metamorphic action on sediments rich in clay minerals has been established. The equivalent of the metamorphic rock containing the gas is shale (English), where the name of shale oil comes from. The level of metamorphism (expressed in terms of temperature and pressure) reached in shale rocks causes gas to migrate (whatever its nature) and therefore does not favor gas accumulation in this type of rock. To align the terminology to international literature and nomenclature, we will refer to this type of gas further as shale gas.

The exploitation of this type of deposit requires a more complex technology than that involved in the operation of conventional gases and it is characteristic of the oblique and horizontal drilling over long distances. For this reason, this typology of the deposit together with the technology involved for its exploitation is also called unconventional. Drilling techniques have been developed and originally applied in the United States, where there are already over 50,000 shallow wells.

The success achieved determined the application of the technique in other areas where this type of deposit is present. Already Canada has identified similar shale gas deposits in Apalai and British Columbia. In Europe, Poland has the largest deposits of shale gas, estimated to be 5,300 billion cubic meters. In Ukraine, the shale gas reserves amount to at least 30 trillion cubic meters.

The amount of $\mathrm{CO}_{2}$ resulting from the combustion of the gas must be added to the $\mathrm{CO}_{2}$ resulting from the oil used for the construction and operation of the wells as well as the methane losses to the atmosphere during the extraction and transport. According to an article by Robert Howarth at Cornell University, published in the Climatic Change Letters, based on data available from the US Environmental Protection Agency (EPA) and the US gas industry itself, the carbon footprint in shale gas is worse than that of conventional shafts. Indeed, each well loses from 3.6 to $7.9 \%$ of its gas in the atmosphere (from 30 to $200 \%$ more than for a conventional shaft). The same study proposes to no longer apply to this methane lost in the atmosphere the Global Warming Potential index (GWP) retained by the fourth Climate Change Expert Group (IPCC) report, i.e., 72 times the $\mathrm{CO}_{2}$ heating potential over a 20 -year period, but the index proposed in 2009 by NASA's Drew Shindell, up 23\% on average, because it integrates climate-specific
Greenhouse Gas (GHG) interactions with particular aerosols. In this case, the carbon footprint of a shale gas well in 20 years would be 20 to $50 \%$ higher than if coal were used to produce the same amount of energy.

Official concerns about the environmental and health impacts of hydraulic fracturing occur in 2010, notably through EPA, which, at the request of the US Government, decided to study this impact on "drinking water and public health" and by publishing a first synthesis in the American Scientist magazine, but it seems that three years ago they were found in the US more significant gas leakage into the environment and contamination of superficial groundwater with gas and fracturing fluids (following the French Oil Institute, due to a cement deficiency in the upper part of the drilling). The US Congress reserved a budget for these issues in 2010 and the EPA has entrusted its own Office of Research and Development (ORD) with a scientific study launched in 2011 after expert workshops and consultations (between June-September 2011) and public appeal to experts on the possible effects of hydraulic fracturing on drinking water resources. EPA provides for the evaluation of the study by neutral experts. Citizens 'and associations' demonstrations have taken place in various countries, opposed to this way of extraction, as well as the continued use of fossil energies.

Natural gas is a flammable gas that forms as a reservoir in the deep earth layers. Natural gas is associated with oil deposits and their formation processes are similar. The composition of natural gas mainly consists of methane, distinguishing it from the chemical composition.

Natural gas is a mixture of gases, which can be very different after the deposit. Most of this is methane, to which sometimes appreciable amounts of saturated hydrocarbons (alkanes), methane $\left(\mathrm{CH}_{4}\right)$, ethane $\left(\mathrm{C}_{2} \mathrm{H}_{6}\right)$, propane $\left(\mathrm{C}_{3} \mathrm{H}_{8}\right)$, unsaturated hydrocarbons, alkenes or olefins and aromatic hydrocarbons or arene which in the chain of the chemical formula have a double bond $(=)$ as the ethylene (ethylene) $\mathrm{C}_{2} \mathrm{H}_{4}$. Alkanes having an annular chemical structure are also called cycloalkanes, having the general chemical formula $\mathrm{C}_{\mathrm{n}} \mathrm{H}_{2 \mathrm{n}}$. Alchenes may also have cyclic forms such as cyclopentane.

Alkins are hydrocarbons containing several triple chemical bonds, the most representative being ethylene (acetylene): $\mathrm{C}_{2} \mathrm{H}_{2}$. The last most important group of unsaturated hydrocarbons is benzene having a cyclic structural formula: $\mathrm{C}_{6} \mathrm{H}_{6}$; of a subgroup of these aromatic hydrocarbons is naphthalene: $\mathrm{C}_{10} \mathrm{H}_{8}$, whereas terpenes (turpentine) are not chemically pure hydrocarbons.

Natural gas also contains: Condensed gas vapors, which are also referred to as wet gases, hydrogen sulphide $\left(\mathrm{H}_{2} \mathrm{~S}\right)$, which require sulfur removal and up to $9 \%$ carbon dioxide $\left(\mathrm{CO}_{2}\right)$ that diminishes gas quality.

Generally, natural gas has $85 \%$ methane, $4 \%$ other alkanes (ethane, propane, butane, pentane) and $11 \%$ inert 
(non-burning) gases. Particularly valuable are natural gases containing helium, these gases being the main source of helium production.

Natural gas originates through processes similar to the oil it is frequently found. The gas is formed from dead microscopic organisms (algae, plankton) being isolated from atmospheric air, in the presence of high temperatures and pressures, conditions that arose through sedimentation on the seabed and are subsequently covered by impermeable layers of earth.

Most of the natural gas was formed 15 to 600 million years ago, being associated with oil fields, rarely can be found the unique oil or gas deposits. For the first time in 1844 natural gas was found in Europe in the area of the eastern railway station in Vienna, followed by new discoveries in 1892 through the drilling in Wels, Austria. Large gas fields are located in North Field (over 900 TCF or 25 billion $\left(10^{2}\right) \mathrm{m}^{3}$ ) in Qatar (the peninsula of Arabia) and Urengoi (over 300 TCF or 8 billion $\left(10^{2}\right)$ $\mathrm{m}^{3}$ ) in Siberia, Russia. Also, there are supposedly more gas deposits in Iran.

It can be transported by pipeline or other means of transport in compressed state or in liquid state, currently being used on a larger scale as a replacement for gasoline.

Gas drying is the process of removing water vapor, which is part of the gas preparation methods before use. The removal of water from the gas is important because the drying of the gas eliminates the possibility of crystallization. These are solid impurities that block the pipes and damage the fittings. The degree of drying of the gas is determined such that crystalline hydrides are formed only below $-8^{\circ} \mathrm{C}$.

The net quantity of gas exploited in 2004 was 2.689 billion $\mathrm{m}^{3}$, of which $22 \%$ is for Russia, $20 \%$ for the United States, $6.8 \%$ for Canada, 3.6\% for the United Kingdom, 3\% for Algeria and 17.2\% Indonesia, the Netherlands, Uzbekistan, Iran, Argentina, Mexico, Saudi Arabia, Malaysia and Germany and $0.6 \%$ of Austria.

Natural gas covers $24 \%$ of the world's energy needs. Gas fields, as a rule, are under pressure, which makes it easier to exploit. The global gas reserves estimated in 2004 are 170.942 billion $\mathrm{m}^{3}$ and 185 billion tons (SKE) that would cover the needs for a period of 67 years. Of this gas, 2.830 billion $\mathrm{m}^{3}$ belong to the Near East (Arabian Peninsula, a part of North Africa), 64.020 billion $\mathrm{m}^{3}$ to Europe and GUS (Soviet Union), 14.210 billion $\mathrm{m}^{3}$ to Asia and Australia, 14.060 billion $\mathrm{m}^{3}$ to Africa, 7.320 billion $\mathrm{m}^{3}$ North America and 7.100 billion $\mathrm{m}^{3}$ South America.

Global demand is expected to jump 5.1 trillion cubic meters (tmc) by 2035, with $1.8 \mathrm{tcm}$ more than in 2011 .

Romania has proven natural gas reserves of 100 billion cubic meters. Most of Romania's natural gas resources are located in Transylvania, Moldova, Muntenia and the Black Sea, with approximately $75 \%$ of them in Transylvania, especially in the Mureş and Sibiu counties. The largest natural gas field in Romania is in Deleni, discovered in 1912 and is between Băgaciu and Mureş County with proven reserves of 85 billion cubic meters. Other natural gas fields are Filitelnic (40 billion cubic meters), the Roman-Secuieni field (24 billion cubic meters), Voitinel (11.8 billion cubic meters), Gherceşti (11 billion cubic meters) and Sărmăşel 10 billion cubic meters), all with reserves higher than 10 billion cubic meters. Currently, Romania has its third gas reserve in the European Union, right after the Netherlands and the United Kingdom.

Romania's total natural gas consumption in 2006 was 17 billion cubic meters of which $70 \%$ of domestic origin and $30 \%\left(5.1\right.$ billion billion $\left.\mathrm{m}^{3}\right)$ of import. The origin of this quantity of natural gas is as follows:

\section{- Romgaz: 35.89\% (6.1 billion $\left.\mathrm{m}^{3}\right)$ \\ - Petrom and others: $34.11 \%\left(5.8\right.$ billion $\left.\mathrm{m}^{3}\right)$}

In 2014, however, gas imports fell to only 1 billion $\mathrm{m}^{3}$, or $7.5 \%$ of Romania's total consumption. Similarly, there was a drop in consumption to 12 billion. $\mathrm{M}^{3}$. The main reason for the decrease in consumption and imports was the adjustment of the industrial sector, mainly chemistry and petrochemistry and the structure of domestic gas coming into consumption in September 2014 was:

- OMV Petrom Intern 54,69\%

- Domestic Romgaz 41,04\%

- Amromco Energy 3.06\%

- Others

- Natural gas supplies about $40 \%$ of Romania's energy consumption.

- The gas market exceeded 4 billion euros in 2006

- Romania's gas reserves were estimated at 630 billion cubic meters

- Approximately $62.5 \%$ of the total national production is extracted on the territory of Mureş County

Romania has important non-conventional gas resources. These are the gases that have remained in the harsh rocks or the migration route. Petroleum companies, Chevron, Mol and Avere Energy, have licenses for unconventional gas exploration in Romania, the first in Dobrogea, the other two in the west of the country. For economic reasons, only conventional gas fields have generally been exploited, "said Alexandru Patruti, president of the National Agency for Mineral Resources (ANRM).

In 2000, the Romanian State ordered the reorganization of Romgaz, resulting in several companies:

- Explains with the main field of extraction of natural gas

- Depogaz for storage of natural gas 
- Transgaz which deals with the transport of natural gas on the national territory

- Distrigaz Nord and Distrigaz Sud with the object of distributing natural gas to domestic and industrial users

- Later, in 2001, Exprogaz and Depogaz were merged into one with the initial name Romgaz

In June 2005, the Romanian State sold to strategic investors the majority stake of $51 \%$ of the shares of Distrigaz Nord and Distrigaz Sud for approximately EUR 300 million each.

At present (November 2007), the Romanian State will launch $10 \%$ of Transgaz shares for listing on the Bucharest Stock Exchange.

The natural gas distribution market is divided by 34 operators that serve approximately 2.5 million customers in 1,700 locations. At the top of the list are Distrigaz Nord with $47.53 \%$ and Distrigaz Sud with $46.68 \%$, followed by Congaz by $0.97 \%$, Petrom Distribuție by $0.84 \%$, Gaz Vas Vaslui by $0.79 \%$ and Vital Gaz with $0.39 \%$.

Regarding the imports of natural gas, according to the quantity of imported gas, the ranking is as follows: Distrigaz Sud - 30,59\%, Distrigaz Nord - 26,76\%, Romgaz - 13,87\%, Wiee Romania - 11,19\%, Electrocentrale Bucharest - 11.09\%, Transgaz - 2.77\%, Termoelectrica $2.07 \%$. All imports of natural gas from Romania are made from the Russian market, from Gazprom.

The gas storage capacity in 2006 is about 3 billion cubic meters in the 8 existing warehouses. In 2000 the capacity was 1.34 billion cubic meters.

OMV Petrom and Exxon Mobil announced on February 23, 2012, the discovery of an important natural gas deposit in the Black Sea that could cover Romania's imports for 20 years. The deposit discovered by the two companies in the Black Sea was originally estimated at 42-84 billion cubic meters, equivalent to the total consumption of Romania for 3-6 years. The Romanian gas market is 14.2 billion cubic meters per year in 2012 .

The deposit was discovered after the drilling of the Domino-1 shaft by ExxonMobil, the first deep sea operation off the Romanian shore, more than 3,000 meters below sea level. Domino-1 is located in the Neptune Bloc, 170 kilometers from the shore, in waters with a depth of about 930 meters.

First extraction could take place at the earliest by the end of the decade, "says OMV Petrom.

Radu Dudău, energy specialist at Romania Energy Center (ROEC) said: "We will have to wait for other results to see if the reserve can be commercially exploited. We have to take into account that the deposit is at a depth of 1,000 meters and at an unobtrusive shore distance of 170 kilometers. "But also the fact that the exploration was made by major companies (OMV Petrom and Exxon Mobil) using technologies "The costs are great, we are talking about investments that can reach billions of dollars," warned Radu Dudău.

\section{Results}

Since September 2015, there has been a series of catastrophic fires on board gas vehicles called "Gas Buses" (Mercedes-Benz OC 500 LE). It has been discovered that there are possible failures in the fire extinguishing system installed in the engine compartment behind the bus. A bus fire at Elizabeth Quay bus station (formerly known as Esplanade Busport) in July was reported to have been caused by a cooling cell. A series of unique fires occurred in two of the Mercedes-Benz O405NH diesel buses, both caused by clogged ventilation belts. No one has been injured in possible bus fires, while drivers have responded quickly and evacuated passengers before the fires become fatal. Compared to the number of fires in gasoline vehicles and the severity of explosions produced over time, methane gas accidents can be considered not only limited, but also minor and insignificant. This is a serious argument for serious discussions about their massive, global introduction, even in the immediate future. In addition, combustion in internal combustion engines is about $90 \%$ lower than conventional gasoline engines. Global gas reserves have increased significantly and are steadily increasing and their consumption only in stove households cannot already consume a large world production of methane gas. For this reason, the price of classic (petroleum) fuel has recently begun to decline over a long period of time (about 40 years), which has only increased steadily. Now we can extract shale gas, that is, deep gas, which has revived the light industry of the world's hydrocarbons (gas).

Compressed Natural Gas (CNG) (high pressure methane) is a fuel that can be used instead of gasoline, diesel and propane/LPG. Combustion with CNG produces fewer unwanted gases than the fuels mentioned above. It is safer than other fuels in the event of a spill, because natural gas is lighter than air and disperse rapidly when released. CNG can be found above the oil fields or can be collected from landfills or wastewater treatment plants where it is known as biogas (Natural Gas Vehicle Availability, U.S. Department of Energy).

$\mathrm{CNG}$ is made by compressing natural gas (consisting mainly of methane, $\mathrm{CH}_{4}$ ) to less than $1 \%$ of the volume occupied at standard atmospheric pressure. It is stored and distributed in heavy containers at a pressure of 20-25 MPa (2900-3,600 psi), usually in cylindrical or spherical shapes.

$\mathrm{CNG}$ is used in conventional gasoline/internal combustion engines that have been modified or only in CNG engine machines ("dedicated") with a separate gasoline range to expand the range of fuel to another fuel. Gas vehicles are increasingly used in Iran, especially Pakistan, the Asia Pacific region, Indian capital Delhi and other major cities such as Ahmedabad, Mumbai, Pune, Kolkata and cities such as Lucknow, Kanpur, etc. Transit buses and school trains. 
The cost and location of fuel storage tanks is a major barrier to wider/faster adoption of GNC as fuel. Also, municipal governments, public transport vehicles were the most visible early users because they can quickly reimburse the money invested in the new fuel (and usually cheaper). Despite these circumstances, the number of vehicles in the world using GNC has steadily increased $(30 \%$ per year). Now, due to the constant growth of the industry, the cost of storing these fuels has been reduced to a much more acceptable level. Especially for GNG type 1 and 2 tanks, many countries can make reliable and cost-effective tanks for conversion (The Italian community of Natural Gas Vehicles).

The volumetric density of CNG energy is estimated at $42 \%$ of liquefied natural gas and $25 \%$ in diesel.

At the global level, by 2011, 14.8 million gas vehicles used by Iran, 2.86 million, Pakistan (2.85 million), Argentina (2.07 million), Brazil (1.7 million) and India (1.1 million) with the Asia-Pacific region having 5.7 million NGV, followed by Latin America, with nearly four million vehicles.

Several manufacturers (Fiat, Opel/General Motors, Peugeot, Volkswagen, Toyota, Honda and others) are selling two-wheeled cars. In 2006, Fiat introduced Siena Tetrafuel on the Brazilian market, equipped with a $1.4 \mathrm{~L}$ FIRE engine running on E100, E25 (Brazilian standard gasoline), ethanol and CNG.

Any existing gasoline vehicle can be converted into a dual fuel (gas/CNG) vehicle. Authorized inventories can update and involve the installation of a CNG cylinder, plumbing, CNC injection system and electronics. The cost of installing a CNG conversion set can often amount to $\$ 8,000$ for cars and light trucks and is usually reserved for vehicles that travel multiple miles per year. CNG costs about $50 \%$ less than gasoline and emits up to 90\% less emissions than gasoline.

CNG locomotives are operated by several railways. Valea Vinului Valea Napa managed to modernize a diesel engine for the exploitation of natural gas by 2002. This locomotive has been transformed into a modernized fuel injection system in May 2008 and is now the main Valley Wine engine. Ferrocarril Central Andino Peruvian CNG has executed a locomotive in a freight train locomotive since 2005. CNGs are usually diesel generators that have been converted into compressed gas instead of diesel generators to generate the electric motor that drives the engines of traction. Some CNG locomotives can ignite the cylinders only when there is an energy demand, which in theory gives them more fuel efficiency than conventional diesel engines. CNG is also cheaper than gasoline or diesel and pollutes much less (Mitchell, 2015).

\section{Benefits}

The natural gas vehicle has lower maintenance costs than other hydrocarbon-fueled vehicles.
CNG fuel systems are leak proof, preventing leakage due to leakage or evaporation.

Increase the service life of lubricating oils because the CNG does not contaminate or dilute the oil of the crankcase.

Being a gaseous fuel, the CNG mixes gently and uniformly in the air.

CNG is less likely to ignite on hot surfaces because it has a high auto-ignition temperature $\left(540^{\circ} \mathrm{C}\right)$ and a narrow range $(5-15 \%)$ of flammability.

CNG-fueled vehicles are considered safer than gasoline vehicles.

\section{Less Pollution and More Efficiency}

CNG emit 22 kilograms of pollution significantly less than gasoline or oil in the event of combustion (e.g., carbon dioxide $\left(\mathrm{CO}_{2}\right)$, Uncleaned Hydrocarbons (UHC), carbon monoxide (CO), Nitrogen Oxides (NOx) kilograms of $\mathrm{CO}_{2}$.

Due to low carbon dioxide emissions, switching to GNC can help mitigate greenhouse gas emissions. However, natural gas leakage (both in direct use and in fuel production and delivery) is an increase in greenhouse gas emissions. The ability of $\mathrm{CNG}$ to reduce greenhouse gas emissions over the life of the fuel will depend on the natural gas source and the fuel it replaces.

Greenhouse gas emissions from natural gas in California are 67.70 grams of $\mathrm{CO}_{2}$ per megawatt $\left(\mathrm{gCO}_{2} \mathrm{e} / \mathrm{MJ}\right)$ of CARB (California Air Resources Board), with about $28 \%$ on this market $\left(95.86 \mathrm{gCO}_{2} \mathrm{e} / \mathrm{CNG}\right.$ produced from waste biogas was found by CARB to have the smallest greenhouse gas emissions of any analyzed fuel with a value of $11.26 \mathrm{gCO}_{2} \mathrm{e} / \mathrm{MJ}$ (more than $88 \%$ lower than conventional gasoline) on January 12, 2010.

\section{Disadvantages}

Compressed natural gas vehicles require more fuel storage than conventional gasoline vehicles. Because it is a compressed gas, rather than a liquid like gasoline, GNC takes up more space for each Gallon Of Equivalent Gas (GGE). However, the tanks used for CNG storage occupy space in the boot of a car or in a bed in a modified truck to operate additionally on CNG. This problem is solved for factory-made GNG vehicles, which install tanks under the body, leaving the trunk free (e.g., Fiat Multipla, the new Fiat Panda, Volkswagen Touran Ecofuel, Volkswagen Caddy Ecofuel, Chevy Taxi like Peru). Another option is roof installation (usually on buses), which still requires a solution to structural resistance problems. In 2014, a test (of the Danish Technological Institute) of heavy duty Euro6 for $\mathrm{CNG}$ and diesel showed that GNC had higher consumption, less reliability, the same noise produced, but the NOx and particulate emissions were much lower. 


\section{Standardization Issue}

The lack of codes and harmonized standards in international jurisdictions is another barrier to NGV market penetration. The International Organization for Standardization has an active technical commission working on a standard for gas station for vehicles.

Despite the absence of harmonized international codes, gas vehicles have a world-wide safety record. Existing international standards include ISO 14469-2: 2007 for nozzles and containers for CNG vehicles and ISO 15500-9: 2012 specifies the tests and requirements for the pressure regulator.

The NFPA-52 covers the safety standards of US cars.

\section{Comparison with other Gaseous Fuels}

Compressed Natural Gas (CNG or CNG) is often confused with Liquefied Natural Gas (LNG). Both forms of natural gas are stored. The main difference is that GNC is stored at ambient temperature and high pressure, while LNG is stored at low temperature and close to atmospheric pressure. Under these storage conditions, LNG is a liquid and GNC is a supercritical fluid. CNG has a lower cost of production and storage compared to LNG because it does not require expensive cooling and cryogenic tanks. However, CNG requires a much higher volume to store the energy equivalent of gasoline or diesel and the use of very high pressures (3000 to 4000 psi or 205 to 275 bar). Consequently, LNG is often used to transport natural gas over long distances in ships, trains or pipelines and the gas is then converted to GNC before it is distributed to the end user (Mitchell, 2015).

GNC can also be stored in experimental version under low pressure in a form known as Adsorption Of Natural Gas (ANG) at a pressure of 35 bar (500 psi, gas pressure in natural gas pipelines) in various types of sponge and organic frames MF). Fuel is maintained at an energy density similar to or greater than CNG. This means that vehicles can be recharged from the natural gas network without additional gas compression, fuel tanks being weakened and made from lightweight and weaker materials, a huge advantage.

The urgent need to introduce $\mathrm{CNG}$ vehicles into vehicles:

Compressed natural gas is sometimes mixed with hydrogen (HCNG), which increases the hydrogen/carbon ratio of the fuel and gives it a flame speed of up to eight times the CNG. Hydrogen burns about 10 times faster than gas or gasoline. For this reason, the direct burning of the engines was very difficult due to the danger of high explosion. The solution had to be burned in specialized burners rather than in engines in the cells of "combustion cells" as stored in bee tanks. However, the hydrogen problem has not yet been fully solved, a chance for future resources as water can be dissolved in hydrogen and oxygen directly into the vehicle, oxygen is released into the atmosphere and hydrogen is sent to the combustion device, eliminating special hydrogen tanks and their heavy fuel by directly feeding the vehicle with water or salt water in another experimentally used variant. Decomposition of water with low energy losses for the production and use system is no longer a problem, as nanotechnologies have developed. The systems are not yet sufficiently homologated and tested the huge hydrogen pool in the water will have to wait a while. But because it can be contaminated with gasoline and diesel, hydrocarbon products are more than exhaustive and electric motor systems still have serious problems of storage, charging, reliability, self-management since the year 200, especially in the case of motor vehicles.

Gas reserves are not only much bigger and bigger than oil, but shale gas, that is, deep gas, has been discovered in huge quantities that have not yet been exploited to a very high depth, but now that modern technologies have already begun to be exploited only in some regions of the world and the quantities extracted, stored and used are very large, even impressively large and even bigger. Their use in the future implies the need for their massive burning somewhere. Only gourmets around the world can not handle these massive global quantities. There is no point in burning them in thermal power plants, now that nuclear fission power produces massive heat and wind and solar farms are booming and nuclear fusion is almost in practice and will lead mankind to infinite practice (Mitchell, 2015).

In other words, sustainable energy, renewable, cheap, clean and friendly energy issues have already been resolved and extended every day.

But at the same time, the extremely complex problem of the electric car requires a further delay for a possible intrusion into the world vehicle market, but is still at the stage of experimentation, research, development and gradual unfolding of hot winter cities.

The hydrogen vehicle has already been implemented, but it did not give birth and even the "fuel cell" method could not accelerate quickly and especially the massive program started in the G8 crucial in 2009. As I said, energy storage of water and water, although advanced experimental and technological in many constructive variants, two of which are already separated; the option still needs time for calibration and final implementation, which cannot be fully appreciated (exactly).

Under these circumstances, the massive introduction of cars and gas buses (GNC method) or even hydrogenenriched gas (HCNG) is imperative for a transition period of at least 50 years. If the method will provide the already anticipated benefits and, in addition, the other possibilities will not increase rapidly over the next 50 years, it is possible to prolong the use of GNC vehicles for another 200 years (Mitchell, 2015).

Iran, Pakistan, Argentina, Brazil and China have the largest number of CNG-run vehicles in the world. 
Although the figure is very high, nearly 20 million vehicles running on global methane compared to the global fleet of gasoline and diesel with over one billion vehicles, the current volume of gas vehicles seems to be insignificant. However, account should be taken of the fact that other types of vehicles currently circulating in the world are even less penetrating, such as hybrids, hydrogen, including combustion cells and electric motors, have entered massive maritime traffic. In the 1960s, trolleybuses have very few drawbacks. If we are talking about electric cars running today or electric buses all over the world, we will notice that they are actually insignificant, strange and even inappropriate. Under these circumstances the figure of about 20 million gas vehicles in the current world becomes important and even a starting point.

\section{Latin America}

CNG vehicles are commonly used in South America, where these vehicles are mainly used as taxis in major cities in Argentina and Brazil. Normally, standard gasoline vehicles are upgraded to specialist shops, involving the installation of the gas cylinder in the luggage compartment, the $\mathrm{CNG}$ and the electronic injection system. Argentina and Brazil are the two countries with the largest fleet of CNG vehicles with a total combined perfume of over 3.4 million vehicles by 2009. The conversion was facilitated by a substantial price difference with liquid and CNG fuels.

Since 2009, Argentina has $1,807,186$ NGVs with 1,851 power plants across the country or $15 \%$ of all vehicles; and Brazil had 1,632,101 vehicles and 1,704 fuel stations with a higher concentration in the cities of Rio de Janeiro and São Paulo.

Colombia had a NGV fleet of 300,000 vehicles and 460 fuel stations since 2009. Bolivia has increased its fleet from 10,000 in 2003 to 121,908 units in 2009, with 128 fuel stations. Peru had 81,024 NGVs and 94 gas stations in 2009, but this number is expected to increase while Peru is on the largest gas reserves in South America. In Peru, several factory wagons have tanks installed under the body of the vehicle, leaving the trunk free. Among the models built with this feature are Fiat Multipla, the new Fiat Panda, Volkswagen Touran Ecofuel, Volkswagen Caddy Ecofuel and Chevy Taxi. Other countries with significant NGV fleets are Venezuela $(15,000)$ and Chile $(8,064)$ in 2009.

\section{Asia}

In Singapore, $\mathrm{CNG}$ is increasingly used by public transport vehicles, such as buses and taxis, as well as freight vehicles. However, according to Channel NewsAsia, on April 18, 2008, some privately owned car owners in the country turn their gasoline into gasoline vehicles, undoubtedly motivated by high gasoline prices. The initial cost of converting a typical double fuel vehicle to C. Melchers' conversion workshop, for example, is about $\$ 3,800$; with the promise of real savings that longterm vehicles with dual fuel would bring.

Currently, Singapore has five gas stations. SembCorp Gas Pte Ltd. runs Jurong Island Station and together with Singapore Petroleum Company, the Jalan Buroh power plant. Both stations are located in the western part of the country. Another station on the continent is in Mandai Link to the north and is operated by SMART Energy. SMART also has a second stop on Serangon North Ave 5, which was set up at the end of March 2009; The fifth and largest station in the world was opened by the UNION Group in September 2009. This station is recognized by Guniness World Records as the largest in the world with 46 power hoses. This station is located in Toh Tuck. The Union group, which operates 1000 Toyies Wishies Toyies, intends to introduce three other iron stations and to increase the CNG taxi fleet to 8,000 units.

Being a key incentive for using this green fuel, Singapore has a cost reduction for GNC users. Inaugurated for the first time in January 2001, GVR grants a $40 \%$ discount to the OMV cost (open market value) for newly registered cars. This initiative will be completed by the end of 2012 because it believes that the "critical mass" of CNG vehicles would have been built.

The Ministry of Transport of Myanmar adopted a law in 2005 that provided for the transformation of all public transport vehicles - buses, trucks and taxis into CNG. The government has allowed several private companies to deal with the conversion of existing gasoline and gasoline and to begin importing CNG buses and taxis. Accidents and rumors of accidents, partly fueled by Myanmar's position in local oil policy, discouraged citizens from using $\mathrm{CNG}$ vehicles, although almost all Yangon taxis and the public bus, the largest city in Myanmar, operate on CNG. GNG stations have been set up around Yangon and other cities, but the lack of electricity means the vehicles have to wait for hours to fill their gas containers. Opposition movements in Burma oppose conversion to CNG because it accuses companies of junta protocols and also that petrodollars gained by the regime would rather go to defense than to improve the infrastructure or welfare of the people.

In Malaysia, the use of CNG was initially introduced for taxis and limousines at the airport in the late 1990s, when new CNG cabins were launched, while taxi operators were encouraged to send existing taxis for a full engine conversion. The practice of using GNC remained largely limited to taxis prevailing in the Klang Valley and Penang due to lack of interest. There were no incentives for those who, besides taxi owners, use CNC engines, while government subsidies for gasoline and diesel have made conventional road vehicles cheaper to use in the eyes of consumers. Petronas, the state oil company in Malaysia, monopolizes and supplies GNC to 
road users. Starting in July 2008, Petronas operates only about $150 \mathrm{CNG}$ feedstocks, most of which are concentrated in the Klang Valley. At the same time, another 50 were expected by the end of 2008 .

Since fuel subsidies have been eliminated in Malaysia since June 5, 2008, the subsequent price increase of $41 \%$ for petrol and diesel has led to a $500 \%$ increase in the number of newly installed CNG tanks. Proton, the national carmaker, believes that the Waja, Saga and Persona models will be equipped with Prins Autogassystemen CNG kits by the end of 2008, while a local distributor of locally assembled Hyundai vehicles offers new models with CNG kits. Conversion Centers, which also benefited from low-cost operations, also made partial conversions on existing road vehicles, allowing them to run on both gasoline, diesel and $\mathrm{CNG}$ at a cost rate of 3,000-1,500 lei for cars.

In China, companies such as Sino-Energy are active in expanding the GNG footprint in the central cities of the country where at least two gas pipelines are operational.

In Pakistan, the government of Karachi, through the 2004 Supreme Court order, ordered all buses and lifts to travel on $\mathrm{CNG}$ with the intention of reducing air pollution.

In Pakistan, in 2012, the federal government announced plans to phase out $\mathrm{CNG}$ over a period of about three years due to the lack of natural gas that negatively affected the production sector. In addition to limiting electricity production capacity, Pakistan's gas shortage has also led to higher business costs for key industries, including the fertilizer, cement and textile sectors.

Iran has one of the largest distribution networks with GNC and GNC in the world. There are 2,335 CNG power plants with a total of $13,534 \mathrm{CNG}$ nozzles. The number of vehicles burning $\mathrm{CNG}$ in Iran exceeds 3.5 million. Consumption of GNC by the Iranian transport sector is about 20 million cubic meters per day.

\section{Africa}

Egypt ranks among the top $10 \mathrm{CNG}$ adopting countries, with $128,754 \mathrm{CNG}$ vehicles and $124 \mathrm{GNG}$ power plants. Egypt was also the first nation in Africa and the Middle East to open a CNG power plant in January 1996.

The vast majority of 780000 have been produced by the machine over the past two years as dual fuel vehicles and the rest have been converted using market conversion kits into workshops. There are 750 national power plants with another 660 fuel stations under construction and are expected to enter into force. At present, the main problem faced by the industry as a whole is the construction of power plants that remain behind the production of dual fuel vehicles, forcing many to use gasoline.

Nigeria CNG started with a pilot project in Benin City Edo State in 2010 by Green Gas Limited. Green
Gas Limited is a joint venture of NGC (Nigerian Gas Company Ltd.) and NIPCO PLC. In October 2012, approximately seven $\mathrm{CNG}$ stations with about 1,000 CNGs operating in Benin City Edo were built in Benin City Edo. In the city of Benid Edo, major companies such as Coca-Cola use CNG to propel their forklifts, while Edo City Transport Ltd (ECTS) runs several CNG buses.

\section{Europe}

In Italy, there are more than $1173 \mathrm{CNG}$ stations. The use of methane for vehicles began in the 1930s and continued to date.

Since 2008, there has been an expansion of the market for natural gas vehicles (CNG and LPG) due to higher gasoline prices and the need to reduce air pollution emissions. Before 1995, the only way to have a CNG engine was to have a post-market kit. An important producer was Landi Renzo, Tartarini Auto, Prins Autogassystemen, OMVL, BiGAs, ... and AeB for electronic parts used by most kits manufacturers.

Landi Renzo and Tartarini sells vehicles from Asia and South America. Since 1995, biofuel vehicles (petrol/GNC) have been available from several major manufacturers. At present, Fiat, Opel, Volkswagen, Citroën, Renault, Volvo and Mercedes are selling various models of cars and small trucks fueled with gas/GNC. Typically, the CNG components used by most carmakers are actually produced by car kit manufacturers after sales, Fiat uses Tartarini Auto components, Volkswagen uses the Teleflex GFI and Landi Renzo components.

In Belgium, GNC is a very new fuel. At the beginning of 2014, there were only 17 fuel stations, all in Flanders, but the number is now growing rapidly. At the beginning of 2015, there were 29 gas stations in Belgium, all in Flanders. Since January 2017, there are 76 gas stations active in Belgium, most of them in Flanders, since only 7 of them are located in Wallonia or Brussels. As fuel and compared to gasoline, GNC benefits from a favorable tax treatment, with lower excises (although VAT is always paid). Since $\mathrm{CNG}$, such as diesel, is not totally exempt from excise duty, CNG fuel vehicles do not pay a primary charge to partially compensate the state for loss of revenue. Instead, LPG cars pay a road tax in Belgium because LPG is totally exempt from excise duty. Since $\mathrm{CNG}$ is not exempt from excise duty in full, it is allowed in Belgium to connect a machine to the natural gas network and supply the vehicle at home.

The purchase of GNG vehicles is not subsidized by the government, but by Belgian gas producers and distributors. Fiat and Volkswagen sell $\mathrm{CNG}$ machines equipped in the plant in Belgium. At the end of 2013, only 344 CNG machines were operating in Belgium.

In Germany, CNG-generated vehicles will increase to two million units by 2020 . The cost of CNG fuel is between $1 / 3$ and $1 / 2$ compared to other fossil fuels in 
Europe. In 2016, there are approximately 900 CNG stations in Germany and most German carmakers, such as Volkswagen, Mercedes, Opel and Audi, offer CNG engines on most of their models. Augsburg is one of the few cities to run public buses operated by CNG since 2011.

In Turkey, Ankara municipality is increasingly using CNG buses, where the number reached 1090 by 2011. Istanbul started in 2014 with an order of 110 buses. Konya also added 60 buses to its fleet in the same year.

There are 9 GNC power plants in Portugal on September 25, 2017.

In Hungary there are four public CNG filling stations in the cities of Budapest, Szeged, Pécs and Györ. The Szeged Public Transport Company manages buses mainly on $\mathrm{CNG}$.

There are $96 \mathrm{CNG}$ power plants in Bulgaria since July 2011. Some can be found in most of Bulgaria's big cities. There are 22 CNG stations in the capital Sofia, which makes Europe have the largest natural gas hub in Europe. There are also quite a few in Plovdiv, Ruse, Stara Zagora and Veliko Tarnovo, as well as in the Black Sea cities - Varna, Burgas, Nessebar and Kavarna.

CNG vehicles are becoming more and more popular in the country. Fuel is mostly used by taxi drivers because of its much lower price compared to gasoline. At present (July 2015), Sofia is rapidly renewing its public transport fleet with MAN Lion's City buses running on CNG. Also, many companies go to $\mathrm{CNG}$ trucks and even heavy trucks for their day-to-day operations within the city limits.

In Macedonia, there is a CNG station in the capital of Skopje, but it is not intended for the public. Only twenty buses of the Local Public Transport Company were equipped to use a mixture of diesel and CNG. The first commercial CNG station in Skopje is in the advanced stage of development and expects it to start in July 2011.

In Serbia, there are five GNCs, two of which are in the capital of Belgrade and the rest in Pančevo, Kruševac and Čačak.

In Slovenia, there are two CNG power stations in the capital of Ljubljana and Maribor.

In Croatia, there is only one $\mathrm{CNG}$ station located close to the center of Zagreb. At least $60 \mathrm{CNG}$ buses are used as a form of public transport (Zagreb public transport services).

There are five public CNG stations in Estonia - two in the Tallinn capital and the other in Tartu, Pärnu and Narva. Since 2011, Tartu has five Scania-manufactured CNG buses operating on its inner routes.

In Sweden, 90 GNG plants are currently available (compared to about 10 liquefied power plants), currently in the south and west of the country and in the Mälardalen region.

Other power plants of 70-80 GNC are under construction or at an advanced planning stage (finalizations 2009-2010). Several planned power plants are located in the northern part of the country, which will considerably improve the infrastructure for GNC users. There are approx. 14,500 CNG vehicles in Sweden (2007), of which approx. 13,500 are cars and the rest includes buses and trucks. In Stockholm, public transport company SL currently operates $50 \mathrm{CNG}$ buses but has the capacity to operate 500. The Swedish government has recently expanded its subsidies for the development of CNG plants between 2009-12-31 and 2010-12-31.

In Spain, GNC is a very new fuel and the fuel supply network is under development. In Madrid, EMT, uses 672 buses running with GNC. At the beginning of 2015, $35 \mathrm{CNG}$ power plants were located in Spain. Several car brands sell new cars running on $\mathrm{CNG}$, including Fiat, Volkswagen, Seat and Skoda, among others.

Since 2013, there are $47 \mathrm{CNG}$ distribution stations in the Czech Republic, mainly in large cities. Local bus manufacturers SOR Libchavy and Tedom produce CNG versions of their vehicles with roof mounted tanks.

\section{North America}

\section{Canada}

Natural gas has been used as diesel in Canada for over 20 years. With federal and provincial research programs, demonstration projects and NGV market development programs in the $1980 \mathrm{~s}$ and $1990 \mathrm{~s}$, the NGV population increased to over 35,000 by the early 1990s. This assistance led to significant adoption of gas transit buses.

The NGV market began to decline after 1995, eventually reaching the current vehicle population of around 12,000 .

This figure includes 150 urban transit buses, 45 school buses, 9,450 light cars and trucks and 2,400 forklifts and ice-resurfacing. Total fuel use in all Canadian markets was 1.9 PJ (petajoules) in 2007 (or 54.6 million liters equivalent of gasoline), down 2.6 percentage points in 1997. GNC food stations dropped to 134 in 1997 at 72 days. There are 22 in British Columbia, 12 in Alberta, 10 in Saskatchewan, 27 in Ontario and two in Québec. There are only 12 private parking stations.

The Canadian industry has developed CNG trucks and buses, CNG fueled transit buses and light trucks and taxis.

The Fuelmaker Corporation in Toronto, the Honda manufacturer of CNG fueling units, was forced to fail by Honda's parent company in the US for unspecified reasons in 2009. The various Fuelmaker assets were subsequently acquired by Fuel Systems Corporation in Santa Ana, California.

\section{DOOR}

Similarly to Canada, the United States has implemented various NGV initiatives and programs since 1980, but have had limited market support. In 
2000 , there were $105,000 \mathrm{NGVs}$; this figure reached a peak of 121000 in 2004 and fell to 110000 in 2009.

In the United States, federal tax credits are available for the purchase of a new CNG vehicle. The use of GNC varies from state to state; only 34 states have at least one CNG fueling site.

In Texas, Commissar for Railways David Porter launched the Texas Natural Gas Initiative in October 2013 to encourage the adoption of natural gas fuel in the transport, exploration and production sectors. Starting in 2015 , Texas is rapidly becoming a leader in US gas infrastructure with 137 gas stations (private and public gas). Nine months in 2015, Commissioner Porter reports that GNC sales in Texas, LNG sales increased by $78 \%$ in 2014. Commissioner Porter in June 2015: "Natural gas vehicles are developing faster than expected, these collections are almost double compared to the sum collected last year this year, at 15 cents the equivalent of one gallon, the diesel charge of $\$$ $3,033,600$ is equivalent to the sale of $20,224,000$ gallons of natural gas. Texas, \$ 3 million for gas revenues for GNC and LNG by 2015 by 2015 ; 1 September, representing 9 months of tax collection.

In Athens, the Gas and Gas Department of Ala installed a public CNG station on 65 corridors, becoming the only $\mathrm{CNG}$ public station between Birmingham and Nashville in February 2014. Larger vehicles such as trucks are at this power plant. The city also has two non-public GNG stations with a slow capability for its fleet. Athens has added CNG fuel for gas/fuel for police and fire, CNG Honda Civic CNG Heil and $\mathrm{CNG} /$ gasoline to its fleet.

In California, CNG is commonly used in local and county local fleets as well as in public transport (city/school buses). There are 90 public power stations in Southern California and travel from San Diego, so Bay Area to Las Vegas and Utah is routine with the advent of online station maps such as www.cngprices.com. Compressed natural gas is usually available $30-60 \%$ less than the cost of gasoline, especially from California.

The 28 buses that run the local Gwinnett County Transit route run on $\mathrm{CNG} 100 \%$. In addition, about half of Georgia's regional transport fleet, which runs and falls from Gwinnett County Transit, uses CNG.

The Massachusetts Bay Transport Authority has run 360 CNG buses since 2007 and is the largest user in the state.

The Metropolitan Transportation Administration of New York City (MTA) currently has over $900 \mathrm{CNG}$ buses located in Brooklyn, The Bronx and Queens.

Nassau Inter-County Express (or NICE Bus) runs a $100 \%$ Orion $\mathrm{CNG}$ fleet for fixed routing services, consisting of 360 service buses in Nassau, Queens, New York and the western sections of Suffolk County.

The city of Harrisburg, Pennsylvania has passed some of the city's vehicles to compressed natural gas in an effort to save money on fuel costs. Trucks used by the street and the water, canal and gas department have been transformed from gas into $\mathrm{CNG}$.

The personal use of GNC is currently a small niche market, although with current tax incentives and an increasing number of public power plants, it is experiencing an unprecedented increase. Utah has a CNG subsidized power plant at a rate of $\$ 1.57 / \mathrm{GGE}$, while gasoline is over $\$ 4.00 /$ gal.

In another part of the country, retail prices are around $\$ 2.50 / \mathrm{GGE}$, a household gas that compresses gas from residential gas lines under $\$ 1 /$ GGE. Except for conversion to the spare parts market and public vehicle auctions, the only CNG product currently present in the United States is the Honda Civic GX, limited in number and available only at retail outlets.

An initiative, known as the Pickens Plan, calls for expanding the use of $\mathrm{CNG}$ as a standard fuel for heavy vehicles was recently launched by Oleman and contractor T. Boone Pickens. California voters defeated Proposition 10 in the 2008 general election, with a significant margin (59.8 to $40.2 \%$ ). Proposal 10 was a $\$ 5$ billion bond measure, which would offer, among other things, discounts for state-owned car buyers for GNC vehicles.

On February 21, 2013, T. Boone Pickens and Mayor of New York, Michael Bloomberg unveiled a mobile CNG pizzeria. The company, Neapolitan Express, uses alternative energy to drive the truck, as well as $100 \%$ recycled and compostable materials for transport boxes.

Congress has encouraged cars to be converted into GNC with a tax credit of up to $50 \%$ of the cost of conversion and the cost of a CNG feedstock. However, while $\mathrm{CNG}$ is a cleaner fuel, the conversion requires an EPA type certificate. Compliance with the requirements of a type certificate may cost up to $\$ 50,000$. Other non-EPA approved sets are also available. A complete and safe conversion of after-sales products using an EPA-free approved kit can be done for just $\$ 400$ without a drum.

\section{New Implementations}

AT and $\mathrm{T}$ has ordered 1,200 trucks from General Motors in 2012. It is the largest CNG command since General Motors to date. AT and $\mathrm{T}$ has announced its intention to invest up to $\$ 565$ million to use approximately 15,000 alternative fuel vehicles over a 10year period until 2018 to use commercial vehicles to provide and maintain communications, AT and T highspeed customers and AT and T customers.

\section{Oceania}

In the 1970s and 1980s, CNG was commonly used in New Zealand as a result of oil crises, but declined drastically after falling petrol prices. At the peak of natural gas use, $10 \%$ of New Zealand cars have been transformed, approximately 110,000 vehicles. 
For a while, the transport from Brisbane in Queensland, Australia, has adopted a policy of purchasing CNG buses. Brisbane has 215 models Scania L94UB and 324 MAN 18.310 as well as $30 \mathrm{CN}$ CN 313 CNG articulated buses. The State Transit Authority has purchased 100 buses from the Mercedes-Benz OC500LE, which operate in accordance with the Scania L113CRB, Mercedes-Benz O405NH and MercedesBenz O405NH and 254 Euro 5.

In the 1990s Benders Busways in Geelong, Victoria attempted CNG buses for R and D Energy Corporation.

Martin Ferguson, Ollie Clark and Noel Childs appeared in a report at 7:30 which raised the issue of fuel-based fuel as an option for Australian fuel, highlighting the large volumes of LNG currently exported to northwestern Australia.

\section{Discussion}

Considering the current situation, the present paper proposes to extend the use of gas buses to the detriment of the classical ones with diesel which in this way will be replaced either directly or gradually.

The proposal is a very realistic one, as the replacement of current buses on diesel cannot be done with other types of buses in a short period of time, as demanded by environmentalists and by global standards of vigilance. Requests to stop the production of diesel buses are not sustainable and not even realistic and cannot be achieved in another way.

Even Diesel's initial plans to get the engine or vegetable oils extracted from peanuts were never realistic. Such buses need massive amounts of oil or gas to be used permanently, the world park being extremely large.

Even the private automobile fleet has gone well over a billion and is growing steadily, without this growth and development being halted due to the huge global demand for development.

All that can be done is that on the go change the rules already established in the world and this is not easy, but if pressures of the type of exclusion of diesel engines on the market because of the massive and dangerous pollution that they made they will not be realistic as long as something realistic is not required in place.

\section{Conclusion}

Due to the fact that gasoline or diesel engines are very polluting and have not fuel for a long time and electric motors still have a lot of problems and the batteries that have to feed them are still problematic, this paper wants to propose an immediate switch to cars on gas, the fuel being insured for at least 300 years, the system being nonpolluting and the switch from classic to gas engines is simple, natural, without any technical problems.
The present paper proposes the gradual introduction of gas-fueled for thermal engines, firt by phasing out diesel at the buses.

\section{Acknowledgement}

This text was acknowledged and appreciated by Dr. Veturia CHIROIU Honorific member of Technical Sciences Academy of Romania (ASTR) PhD supervisor in Mechanical Engineering.

\section{Funding Information}

Research contract: 1-Research contract: Contract number 36-5-4D/1986 from 24IV1985, beneficiary CNST RO (Romanian National Center for Science and Technology) Improving dynamic mechanisms.

2-Contract research integration. 19-91-3 from 29.03.1991; Beneficiary: MIS; TOPIC: Research on designing mechanisms with bars, cams and gears, with application in industrial robots.

3-Contract research. GR 69/10.05.2007: NURC in 2762; theme 8: Dynamic analysis of mechanisms and manipulators with bars and gears.

4-Labor contract, no. 35/22.01.2013, the UPB, "Stand for reading performance parameters of kinematics and dynamic mechanisms, using inductive and incremental encoders, to a Mitsubishi Mechatronic System" "PN-IIIN-CI-2012-1-0389".

All these matters are copyrighted! Copyrights: 394qodGnhhtej, from 17-02-2010 13:42:18; 463vpstuCGsiy, from 20-03-2010 12:45:30; 631sqfsgqvutm, from 24-05-2010 16:15:22; 933CrDztEfqow, from 07-01-2011 13:37:52.

\section{Author's Contributions}

All the authors contributed equally to prepare, develop and carry out this manuscript.

\section{Ethics}

This article is original and contains unpublished material. Authors declare that are not ethical issues and no conflict of interest that may arise after the publication of this manuscript.

\section{References}

Antonescu, P., 2000. Mechanisms and handlers. Printech Publishing House, Bucharest.

Antonescu, P. and F. Petrescu, 1985. Analytical method of synthesis of cam mechanism and flat stick. Proceedings of the 4th International Symposium on Mechanism Theory and Practice, (TPM' 85), Bucharest. 
Antonescu, P. and F. Petrescu, 1989. Contributions to cinetoelastodynamic analysis of distribution mechanisms. Bucharest.

Antonescu, P., M. Oprean and F. Petrescu, 1985a. Contributions to the synthesis of oscillating cam mechanism and oscillating flat stick. Proceedings of the 4th International Symposium on Theory and Practice of Mechanisms, (TPM' 85), Bucharest.

Antonescu, P., M. Oprean and F. Petrescu, 1985b. At the projection of the oscillante cams, there are mechanisms and distribution variables. Proceedings of the V-Conference for Engines, Automobiles, Tractors and Agricultural Machines, I-Engines and Automobiles, (AMA' 85), Brasov.

Antonescu, P., M. Oprean and F. Petrescu, 1986. Projection of the profile of the rotating camshaft acting on the oscillating plate with disengagement. Proceedings of the 3rd National Computer Assisted Designing Symposium in Mechanisms and Machine Bodies, (MOM' 86), Brasov.

Antonescu, P., M. Oprean and F. Petrescu, 1987. Dynamic analysis of the cam distribution mechanisms. Proceedings of the 7th National Symposium of Industrial Robots and Spatial Mechanisms, (IMS' 87), Bucharest.

Antonescu, P., M. Oprean and F. Petrescu, 1988 Analytical synthesis of Kurz profile, rotating flat cam cam. Machine Building Review, Bucharest.

Antonescu, P., F. Petrescu and O. Antonescu, 1994. Contributions to the synthesis of the rotating cam mechanism and the tip of the balancing tip. Brasov.

Antonescu, P., F. Petrescu and D. Antonescu, 1997. Geometrical synthesis of the rotary cam and balance tappet mechanism. Bucharest.

Antonescu, P., F. Petrescu and O. Antonescu, 2000a. Contributions to the synthesis of the rotary disc-cam profile. Proceedings of the 8th International Conference on Theory of Machines and Mechanisms, (TMM' 00), Liberec, Czech Republic, pp: 51-56.

Antonescu, P., F. Petrescu and O. Antonescu, 2000b. Synthesis of the rotary cam profile with balance follower. Proceedings of the 8th Symposium on Mechanisms and Mechanical Transmissions, (MMT' 000), Timişoara, pp: 39-44.

Antonescu, P., F. Petrescu and O. Antonescu, 2001. Contributions to the synthesis of mechanisms with rotary disc-cam. Proceedings of the 8th IFToMM International Symposium on Theory of Machines and Mechanisms, (TMM' 01), Bucharest, ROMANIA, pp: 31-36.

Aversa, R., R.V. Petrescu, A. Apicella and F.I.T. Petrescu, 2017a. Nano-diamond hybrid materials for structural biomedical application. Am. J. Biochem. Biotechnol., 13: 34-41.

DOI: 10.3844/ajbbsp.2017.34.41
Aversa, R., R.V. Petrescu, B. Akash, R.B. Bucinell and J.M. Corchado et al., 2017b. Kinematics and forces to a new model forging manipulator. Am. J. Applied Sci., 14: 60-80. DOI: 10.3844/ajassp.2017.60.80

Aversa, R., R.V. Petrescu, A. Apicella, F.I.T. Petrescu and J.K. Calautit et al., 2017c. Something about the $\mathrm{V}$ engines design. Am. J. Applied Sci., 14: 34-52. DOI: 10.3844/ajassp.2017.34.52

Aversa, R., D. Parcesepe, R.V. Petrescu, F. Berto and G. Chen et al., 2017d. Processability of bulk metallic glasses. Am. J. Applied Sci., 14: 294-301. DOI: 10.3844/ajassp.2017.294.301

Aversa, R., R.V. Petrescu, A. Apicella and F.I.T. Petrescu, 2017e. Modern transportation and photovoltaic energy for urban ecotourism. Transylvanian Rev. Admin. Sci., 13: 5-20. DOI: 10.24193/tras.SI2017.1

Aversa, R., F.I.T. Petrescu, R.V. Petrescu and A. Apicella, 2016a. Biomimetic FEA bone modeling for customized hybrid biological prostheses development. Am. J. Applied Sci., 13: 1060-1067. DOI: 10.3844/ajassp.2016.1060.1067

Aversa, R., D. Parcesepe, R.V. Petrescu, G. Chen and F.I.T. Petrescu et al., 2016b. Glassy amorphous metal injection molded induced morphological defects. Am. J. Applied Sci., 13: 1476-1482. DOI: 10.3844/ajassp.2016.1476.1482

Aversa, R., R.V. Petrescu, F.I.T. Petrescu and A. Apicella, 2016c. Smart-factory: Optimization and process control of composite centrifuged pipes. Am. J. Applied Sci., 13: 1330-1341. DOI: 10.3844/ajassp.2016.1330.1341

Aversa, R., F. Tamburrino, R.V. Petrescu, F.I.T. Petrescu and M. Artur et al., 2016d. Biomechanically inspired shape memory effect machines driven by muscle like acting NiTi alloys. Am. J. Applied Sci., 13: 1264-1271. DOI: 10.3844/ajassp.2016.1264.1271

Cao, W., H. Ding, Z. Bin and C. Ziming, 2013. New structural representation and digital-analysis platform for symmetrical parallel mechanisms. Int. J. Adv. Robot. Sys. DOI: 10.5772/56380

Dong, H., N. Giakoumidis, N. Figueroa and N. Mavridis, 2013. Approaching behaviour monitor and vibration indication in developing a General Moving Object Alarm System (GMOAS). Int. J. Adv. Robot. Sys. DOI: $10.5772 / 56586$

De Melo, L.F., S.F. Rosário and J.M., Rosário, 2012. Mobile robot navigation modelling, control and applications. Int. Rev. Modell. Simulat., 5: 1059-1068.

Garcia, E., M.A. Jimenez, P.G. De Santos and M. Armada, 2007. The evolution of robotics research. IEEE Robot. Autom. Magaz., 14: 90-103. DOI: 10.1109/MRA.2007.339608

Garcia-Murillo, M., J. Gallardo-Alvarado and E. Castillo-Castaneda, 2013. Finding the generalized forces of a series-parallel manipulator. IJARS. DOI: $10.5772 / 53824$ 
He, B., Z. Wang, Q’ Li, H. Xie and R. Shen, 2013. An analytic method for the kinematics and dynamics of a multiple-backbone continuum robot. IJARS. DOI: $10.5772 / 54051$

Lee, B.J., 2013. Geometrical derivation of differential kinematics to calibrate model parameters of flexible manipulator. Int. J. Adv. Robot. Sys. DOI: $10.5772 / 55592$

Lin, W., B. Li, X. Yang and D. Zhang, 2013. Modelling and control of inverse dynamics for a 5-DOF parallel kinematic polishing machine. Int. J. Adv. Robot. Sys. DOI: 10.5772/54966

Liu, H., W. Zhou, X. Lai and S. Zhu, 2013. An efficient inverse kinematic algorithm for a PUMA560structured robot manipulator. IJARS.

DOI: $10.5772 / 56403$

Mirsayar, M.M., V.A. Joneidi, R.V. Petrescu, F.I.T. Petrescu and F. Berto, 2017. Extended MTSN criterion for fracture analysis of soda lime glass. Eng. Fracture Mechan., 178: 50-59.

DOI: $10.1016 /$ j.engfracmech.2017.04.018

Mitchell, G., 2015. Developing a natural gaspowered bus rapid transit service: A case study. National Renewable Energy Laboratory.

Natural Gas Vehicle Availability, U.S. Department of Energy.

https://www.afdc.energy.gov/vehicles/natural_gas_a vailability.html

Padula, F. and V. Perdereau, 2013. An on-line path planner for industrial manipulators. Int. J. Adv. Robot. Sys. DOI: $10.5772 / 55063$

Perumaal, S. and N. Jawahar, 2013. Automated trajectory planner of industrial robot for pick-andplace task. IJARS. DOI: 10.5772/53940

Petrescu, F. and R. Petrescu, 1995a. Contributions to optimization of the polynomial motion laws of the stick from the internal combustion engine distribution mechanism. Bucharest.

Petrescu, F. and R. Petrescu, 1995b. Contributions to the synthesis of internal combustion engine distribution mechanisms. Bucharest.

Petrescu, F. and R. Petrescu, 1997a. Dynamics of cam mechanisms (exemplified on the classic distribution mechanism). Bucharest.

Petrescu, F. and R. Petrescu, 1997b. Contributions to the synthesis of the distribution mechanisms of internal combustion engines with Cartesian coordinate method. Bucharest.

Petrescu, F. and R. Petrescu, 1997c. Contributions to maximizing polynomial laws for the active stroke of the distribution mechanism from internal combustion engines. Bucharest.

Petrescu, F. and R. Petrescu, 2000a. Synthesis of distribution mechanisms by the rectangular (cartesian) coordinate method. University of Craiova, Craiova.
Petrescu, F. and R. Petrescu, 2000b. The design (synthesis) of cams using the polar coordinate method (the triangle method). University of Craiova, Craiova.

Petrescu, F. and R. Petrescu, 2002a. Motion laws for cams. Proceedings of the 7th National Symposium with International Participation Computer Assisted Design, (PAC' 02), Braşov, pp: 321-326.

Petrescu, F. and R. Petrescu, 2002b. Camshaft dynamics elements. Proceedings of the 7th National Symposium with International Participation Computer Assisted Design, (PAC' 02), Braşov, pp: 327-332.

Petrescu, F. and R. Petrescu, 2003. Some elements regarding the improvement of the engine design. Proceedings of the 8th National Symposium, Descriptive Geometry, Technical Graphics and Design, (GTD' 03), Braşov, pp: 353-358.

Petrescu, F. and R. Petrescu, 2005a. The cam design for a better efficiency. Proceedings of the International Conference on Engineering Graphics and Design, (EGD' 05), Bucharest, pp: 245-248.

Petrescu, F. and R. Petrescu, 2005b. Contributions at the dynamics of cams. Proceedings of the 9th IFToMM International Symposium on Theory of Machines and Mechanisms, (TMM' 05), Bucharest, Romania, pp: 123-128.

Petrescu, F. and R. Petrescu, 2005c. Determining the dynamic efficiency of cams. Proceedings of the 9th IFToMM International Symposium on Theory of Machines and Mechanisms, (TMM' 05), Bucharest, Romania, pp: 129-134.

Petrescu, F. and R. Petrescu, 2005d. An original internal combustion engine. Proceedings of the 9th IFToMM International Symposium on Theory of Machines and Mechanisms, (TMM' 05), Bucharest, Romania, pp: 135-140.

Petrescu, F. and R. Petrescu, 2005e. Determining the mechanical efficiency of Otto engine's mechanism. Proceedings of the 9th IFToMM International Symposium on Theory of Machines and Mechanisms, (TMM' 05), Bucharest, Romania, pp: 141-146.

Petrescu, F.I. and R.V. Petrescu, 2013. Cinematics of the 3R Dyad. ENGEVISTA, 15: 118-124.

Petrescu, F.I. and R.V. Petrescu, 2012a. Kinematics of the planar quadrilateral mechanism. ENGEVISTA, 14: 345-348.

Petrescu, F.I. and R.V. Petrescu, 2012b MecatronicaSisteme Seriale si Paralele. 1st Edn., Create Space Publisher, USA, ISBN-10: 978-1-4750-6613-5, pp: 128.

Petrescu, F.I. and R.V. Petrescu, 2011. Mechanical Systems, Serial and Parallel-Course (in Romanian). 1st Edn., LULU Publisher, London, UK, ISBN-10: 978-1-4466-0039-9, pp: 124. 
Petrescu, F.I. and R.V. Petrescu, 2016a. Parallel moving mechanical systems kinematics. ENGEVISTA, 18: 455-491.

Petrescu, F.I. and R.V. Petrescu, 2016b. Direct and inverse kinematics to the anthropomorphic robots. ENGEVISTA, 18: 109-124.

Petrescu, F. and R. Petrescu, 2016c. An otto engine dynamic model. IJM\&P, 7: 038-048.

Petrescu, F.I. and R.V. Petrescu, 2016d. Otto motor dynamics. GEINTEC, 6: 3392-3406.

Petrescu, F.I. and R.V. Petrescu, 2016e. Dynamic cinematic to a structure 2R. GEINTEC, 6: 3143-3154.

Petrescu, F.I., B. Grecu, A. Comanescu and R.V. Petrescu, 2009. Some mechanical design elements. Proceeding of the International Conference on Computational Mechanics and Virtual Engineering, (MEC' 09), Braşov, pp: 520-525.

Petrescu, R.V., R. Aversa, A. Apicella, M.M. Mirsayar and F.I.T. Petrescu, 2016a. About the gear efficiency to a simple planetary train. Am. J. Applied Sci., 13: 1428-1436. DOI: 10.3844 ajassp.2016.1428.1436

Petrescu, R.V., R. Aversa, A. Apicella, S. Li and G. Chen et al., 2016b. Something about electron dimension. Am. J. Applied Sci., 13: 1272-1276. DOI: 10.3844/ajassp.2016.1272.1276

Petrescu, F.I.T., A. Apicella, R. Aversa, R.V. Petrescu and J.K. Calautit et al., 2016c. Something about the mechanical moment of inertia. Am. J. Applied Sci., 13: $1085-1090$.

DOI: 10.3844/ajassp.2016.1085.1090

Petrescu, R.V., R. Aversa, A. Apicella, F. Berto and S. Li et al., 2016d. Ecosphere protection through green energy. Am. J. Applied Sci., 13: 1027-1032. DOI: 10.3844 /ajassp.2016.1027.1032

Petrescu, F.I.T., A. Apicella, R.V. Petrescu, S.P. Kozaitis and R.B. Bucinell et al., $2016 \mathrm{e}$. Environmental protection through nuclear energy. Am. J. Applied Sci., 13: 941-946. DOI: 10.3844/ajassp.2016.941.946

Petrescu, F.I.T. and J.K. Calautit, 2016a. About nano fusion and dynamic fusion. Am. J. Applied Sci., 13: 261-266. DOI: 10.3844/ajassp.2016.261.266

Petrescu, F.I.T. and J.K. Calautit, 2016b. About the light dimensions. Am. J. Applied Sci., 13: 321-325. DOI: 10.3844/ajassp.2016.321.325

Petrescu, R.V., R. Aversa, B. Akash, R. Bucinell and J. Corchado et al., 2017a. Modern propulsions for aerospace-a review. J. Aircraft Spacecraft Technol., 1: 1-8. DOI: $10.3844 /$ jastsp.2017.1.8

Petrescu, R.V., R. Aversa, B. Akash, R. Bucinell and J. Corchado et al., 2017b. Modern propulsions for aerospace-part II. J. Aircraft Spacecraft Technol., 1: 9-17. DOI: $10.3844 /$ jastsp.2017.9.17
Petrescu, R.V., R. Aversa, B. Akash, R. Bucinell and J. Corchado et al., 2017c. History of aviation-a short review. J. Aircraft Spacecraft Technol., 1: 30-49. DOI: 10.3844 jastsp.2017.30.49

Petrescu, R.V., R. Aversa, B. Akash, R. Bucinell and J. Corchado et al., 2017d. Lockheed martin-a short review. J. Aircraft Spacecraft Technol., 1: 50-68. DOI: 10.3844 jastsp.2017.50.68

Petrescu, R.V., R. Aversa, B. Akash, J. Corchado and F. Berto et al., 2017e. Our universe. J. Aircraft Spacecraft Technol., 1: 69-79. DOI: 10.3844/jastsp.2017.69.79

Petrescu, R.V., R. Aversa, B. Akash, J. Corchado and F. Berto et al., 2017f. What is a UFO? J. Aircraft Spacecraft Technol., 1: 80-90. DOI: $10.3844 /$ jastsp.2017.80.90

Petrescu, R.V., R. Aversa, B. Akash, J. Corchado and F. Berto et al., 2017g. About bell helicopter FCX-001 concept aircraft-a short review. J. Aircraft Spacecraft Technol., 1: 91-96. DOI: 10.3844/jastsp.2017.91.96

Petrescu, R.V., R. Aversa, B. Akash, J. Corchado and F. Berto et al., 2017h. Home at airbus. J. Aircraft Spacecraft Technol., 1: 97-118. DOI: $10.3844 /$ jastsp.2017.97.118

Petrescu, R.V., R. Aversa, B. Akash, J. Corchado and F. Berto et al., 2017i. Airlander. J. Aircraft Spacecraft Technol., 1: 119-148. DOI: 10.3844/jastsp.2017.119.148

Petrescu, R.V., R. Aversa, B. Akash, J. Corchado and F. Berto et al., 2017j. When boeing is dreaming-a review. J. Aircraft Spacecraft Technol., 1: 149-161. DOI: 10.3844 /jastsp.2017.149.161

Petrescu, R.V., R. Aversa, B. Akash, J. Corchado and F. Berto et al., 2017k. About Northrop Grumman. J. Aircraft Spacecraft Technol., 1: 162-185. DOI: $10.3844 /$ jastsp.2017.162.185

Petrescu, R.V., R. Aversa, B. Akash, J. Corchado and F. Berto et al., 20171. Some special aircraft. J. Aircraft Spacecraft Technol., 1: 186-203. DOI: 10.3844 jastsp.2017.186.203

Petrescu, R.V., R. Aversa, B. Akash, J. Corchado and F. Berto et al., 2017m. About helicopters. J. Aircraft Spacecraft Technol., 1: 204-223. DOI: 10.3844/jastsp.2017.204.223

Petrescu, R.V., R. Aversa, B. Akash, F. Berto and A. Apicella et al., 2017n. The modern flight. J. Aircraft Spacecraft Technol., 1: 224-233. DOI: $10.3844 /$ jastsp.2017.224.233

Petrescu, R.V., R. Aversa, B. Akash, F. Berto and A. Apicella et al., 2017o. Sustainable energy for aerospace vessels. J. Aircraft Spacecraft Technol., 1: 234-240. DOI: 10.3844/jastsp.2017.234.240

Petrescu, R.V., R. Aversa, B. Akash, F. Berto and A. Apicella et al., 2017p. Unmanned helicopters. J. Aircraft Spacecraft Technol., 1: 241-248. DOI: $10.3844 /$ jastsp.2017.241.248 
Petrescu, R.V., R. Aversa, B. Akash, F. Berto and A. Apicella et al., 2017q. Project HARP. J. Aircraft Spacecraft Technol., 1: 249-257. DOI: $10.3844 /$ jastsp.2017.249.257

Petrescu, R.V., R. Aversa, B. Akash, F. Berto and A. Apicella et al., 2017r. Presentation of romanian engineers who contributed to the development of global aeronautics-part I. J. Aircraft Spacecraft Technol., 1: 258-271.

DOI: 10.3844 /jastsp.2017.258.271

Petrescu, R.V., R. Aversa, B. Akash, F. Berto and A. Apicella et al., 2017s. A first-class ticket to the planet mars, please. J. Aircraft Spacecraft Technol., 1: 272-281. DOI: 10.3844/jastsp.2017.272.281

Petrescu, R.V., R. Aversa, B. Akash, F. Berto and A. Apicella et al., 2017t. Forces of a 3R robot. J. Mechatron. Robot., 1: 1-14. DOI: $10.3844 /$ jmrsp.2017.1.14

Petrescu, R.V., R. Aversa, B. Akash, F. Berto and A. Apicella et al., 2017u. Direct geometry and cinematic to the MP-3R systems. J. Mechatron. Robot., 1: 15-23. DOI: 10.3844/jmrsp.2017.15.23

Petrescu, R.V., R. Aversa, B. Akash, F. Berto and A. Apicella et al., 2017v. Dynamic elements at MP3R. J. Mechatron. Robot., 1: 24-37. DOI: $10.3844 / j m r s p .2017 .24 .37$

Petrescu, R.V., R. Aversa, B. Akash, F. Berto and A. Apicella et al., 2017w. Geometry and direct kinematics to MP3R with $4 \times 4$ operators. J. Mechatron. Robot., 1: 38-46. DOI: $10.3844 / \mathrm{jmrsp} .2017 .38 .46$

Petrescu, R.V., R. Aversa, A. Apicella, M.M. Mirsayar and S. Kozaitis et al., 2017x. Current stage in the field of mechanisms with gears and rods. J. Mechatron. Robot., 1: 47-57. DOI: $10.3844 /$ jmrsp.2017.47.57

Petrescu, R.V., R. Aversa, A. Apicella, M.M. Mirsayar and S. Kozaitis et al., 2017y. Geometry and inverse kinematic at the MP3R mobile systems. J. Mechatron. Robot., 1: 58-65. DOI: 10.3844/jmrsp.2017.58.65

Petrescu, R.V., R. Aversa, A. Apicella, M.M. Mirsayar and S. Kozaitis et al., 2017z. Synthesis of optimal trajectories with functions control at the level of the kinematic drive couplings. J. Mechatron. Robot., 1: 66-74.

DOI: $10.3844 /$ jmrsp.2017.66.74

Petrescu, R.V., R. Aversa, A. Apicella, M.M. Mirsayar and S. Kozaitis et al., 2017aa. The inverse kinematics of the plane system 2-3 in a mechatronic MP2R system, by a trigonometric method. J. Mechatron. Robot., 1: 75-87.

DOI: $10.3844 /$ jmrsp.2017.75.87
Petrescu, R.V., R. Aversa, A. Apicella, M.M. Mirsayar and S. Kozaitis et al., 2017ab. Serial, anthropomorphic, spatial, mechatronic systems can be studied more simply in a plan. J. Mechatron. Robot., 1: 88-97. DOI: 10.3844/jmrsp.2017.88.97

Petrescu, R.V., R. Aversa, A. Apicella, M.M. Mirsayar and S. Kozaitis et al., 2017ac. Analysis and synthesis of mechanisms with bars and gears used in robots and manipulators. J. Mechatron. Robot., 1: 98-108. DOI: 10.3844/jmrsp.2017.98.108

Petrescu, R.V., R. Aversa, A. Apicella, M.M. Mirsayar and S. Kozaitis et al., 2017ad. Speeds and accelerations in direct kinematics to the MP3R systems. J. Mechatron. Robot., 1: 109-117. DOI: $10.3844 /$ jmrsp.2017.109.117

Petrescu, R.V., R. Aversa, A. Apicella, M.M. Mirsayar and S. Kozaitis et al., 2017ae. Geometry and determining the positions of a plan transporter manipulator. J. Mechatron. Robot., 1: 118-126. DOI: $10.3844 /$ jmrsp.2017.118.126

Reddy, P., K.V. Shihabudheen and J. Jacob, 2012. Precise non linear modeling of flexible link flexible joint manipulator. IReMoS, 5: 1368-1374.

Tabaković, S., M. Zeljković, R. Gatalo and A. Živković, 2013. Program suite for conceptual designing of parallel mechanism-based robots and machine tools. Int. J. Adv. Robot Sys. DOI: 10.5772/56633

Tang, X., D. Sun and Z. Shao, 2013. The structure and dimensional design of a reconfigurable PKM. IJARS. DOI: $10.5772 / 54696$

The Italian community of Natural Gas Vehicles Forum, technical info, maps. http://www.metanoauto.com/

Tong, G., J. Gu and W. Xie, 2013. Virtual entity-based rapid prototype for design and simulation of humanoid robots. Int. J. Adv. Robot. Sys. DOI: $10.5772 / 55936$

Wang, K., M. Luo, T. Mei, J. Zhao and Y. Cao, 2013. Dynamics analysis of a three-DOF planar serialparallel mechanism for active dynamic balancing with respect to a given trajectory. Int. J. Adv. Robotic Sys. DOI: 10.5772/54201

Wen, S., J. Zhu, X. Li, A. Rad and X. Chen, 2012. Endpoint contact force control with quantitative feedback theory for mobile robots. IJARS.

DOI: $10.5772 / 53742$ 